\title{
Manajemen Kurikulum Kelas Unggulan di MI Darul Ulum Wates Ngaliyan Semarang
}

\author{
Dini Hardianti*, Fatkuroji, Silviatul Hasanah
}

Universitas Islam Negeri Walisongo, Semarang, Indonesia

\begin{abstract}
ABSTRAK
Perpaduan kurikulum nasional dan kurikulum lokal yang diterapkan dalam kelas unggulan di MI Darul Ulum Wates Ngaliyan Semarang dengan potensi peserta didik yang memiliki kemampuan lebih yang pastinya membutuhkan pembinaan yang berbeda dan tidak dapat diberikan perlakuan yang sama dengan peserta didik biasa. Penelitian ini mengambil fokus permasalahan yaitu: (1) Perencanaan kurikulum kelas unggulan (2) Pengorganisasian kurikulum kelas unggulan (3) Pelaksanaan kurikulum kelas unggulan, dan (4)Evaluasi kurikulum kelas unggulan. Penelitian ini menggunakan pendekatan kualitatif deskriptif. Hasil penelitian ini menunjukkan bahwa: (1) Perencanaan dilakukan dengan menganalisis konteks, kebutuhan, dan mengidentifikasi standar nasional pendidikan, dilanjut dengan pemilihan atau penetapan tujuan dan penentuan strategi, kebijakan, program, prosedur, metode, sistem, anggaran, dan standar yang dibutuhkan untuk mencapai tujuan pendidikan. (2) Pengorganisasian dilakukan dalam beberapa tahap. Tahap pembagian tugas dan wewenang oleh tim khusus kepada tim pengembang. Tahap pembagian tugas mengajar. Tahap penyusunan jadwal pelajaran dan beban jam mengajar. Tahap penyusunan jadwal kegiatan intrakurikuler dan ekstrakurikuler. (3) Pelaksanaan kurikulum dengan melakukan pembelajaran sesuai prinsip dan model tuntutan kurikulum. (4) Evaluasi kurikulum menggunakan dua macam evaluasi yaitu evaluasi proses pembelajaran dan evaluasi hasil belajar melalui penilaian formatif dan sumatif.
\end{abstract}

Kata kunci: manajemen; kurikulum; kelas unggulan

\begin{abstract}
A combination of the national curriculum and the local curriculum applied in the excellent class in MI Darul Ulum Wates Ngaliyan Semarang with the potential of students who have more abilities requires different coaching and cannot be given the same treatment as ordinary students. This research take the focus of the problem, which includes: (1) Excellent class curriculum planning (2) Excellent class curriculum organizing (3) Implementation of excellent class curriculum, and (4) Evaluation of excellent class curriculum. This research uses qualitative research descriptive. The results of this study indicate that: (1) Planning done by analyzing context, needs, and identify national education standards, continued with selection or setting of objectives and determination of strategies, policies, programs, procedures, methods, systems, budgets, and standards needed to achieve educational goals. (2) Organizing done in several stages. Division of tasks and authority by a special team to the development team. Step division of teaching duties. The stage of preparing a lesson schedule and load teaching hours. Activity schedule preparation stage intracurricular and extracurricular. (3) Implementation of the curriculum with carry out learning accord to the principles and models of demands curriculum. (4) Curriculum evaluation uses two kinds of evaluation namely evaluation of the learning process and evaluation of learning outcomes through formative and summative assessment..
\end{abstract}

Keywords: curriculum; management; excellent class

\section{PENDAHULUAN}

Dalam Undang-undang RI No.20 Tahun 2003 Tentang Sistem Pendidikan Nasional disebutkan bahwa Pendidikan merupakan kunci kemajuan, semakin baik kualitas pendidikan yang diselenggarakan oleh suatu masyarakat/bangsa, maka akan diikuti dengan semakin baiknya kualitas masyarakat/bangsa tersebut. Pendidikan adalah usaha sadar dan terencana untuk mewujudkan suasana belajar dan proses pembelajaran agar peserta didik secara aktif

\footnotetext{
* Corresponding Author.

E-mail address: tete.dhinniy26@gmail.com (D. Hardianti)
} 
mengembangkan potensi dirinya untuk memiliki kekuatan spiritual keagamaan, pengendalian diri, kepribadian, kecerdasan, akhlak mulia, serta keterampilan yang diperlukan dirinya, masyarakat, bangsa dan Negara. ${ }^{1}$ Dari pernyataan tersebut dapat diambil kesimpulan bahwa mengembangkan dan meningkatkan kualitas pendidikan itu sangat penting dan harus di lakukan.

Pengalaman pendidikan yang sesuai dengan minat, bakat, serta kemampuan intelektual siswa sangat dibutuhkan untuk anak berbakat. Anak berbakat tidak akan terlihat bakatnya jika kegiatan pembelajarannya terlalu mudah, monoton dan tidak ada tantangan, sehingga bakat anak yang unggul tersebut tidak terlihat. Perhatian sangat diperlukan bagi anak-anak berbakat agar anak tersebut dapat mengatasi kesulitan-kesulitan yang dihadapi dalam mewujudkan bakatbakatnya yang unggul. Anak berbakat sebaiknya mempunyai kurikulum tersendiri. Tumbuh kembangnya kreativitas anak berbakat biasanya didukung dari pengembangan kurikulum yang baik. Kurikulum regular berlaku bagi semua siswa, sedangkan kurikulum kelas unggulan digunakan untuk menampung pendidikan berbagai kelompok belajar termasuk kelompok anakanak berbakat. Dalam kurikulum tersebut terdapat komponen-komponen yang saling terkait. Komponen tersebut adalah: a. Materi pengalaman belajar yang menumbuhkan kreativitas; b. Terjadi penanjakan dinamis mental dan tindakan kreatif; c. Berorientasi pada proses; d. Komponen yang bersifat teknis. Bondi Wiles Damayati dan Mudjiono mengemukakan bahwa pengembangan kurikulum yang terbaik adalah proses yang meliputi banyak hal yaitu; (1) Kemudahan suatu analisis tujuan, (2) rancangan suatu program, (3) penerapan serangkaian pengalaman yang berhubungan, dan (4) peralatan serta evaluasi proses. ${ }^{2}$

Sebagaimana keputusan pemerintah yang sudah mengharuskan semua sekolah/madrasah menyelenggarakan kegiatan pembelajaran berdasarkan Kurikulum Nasional Tahun 2013. Kurikulum 2013 ini telah dijalankan MI Darul Ulum sejak tahun pelajaran 2015-2016. Kurikulum Nasional di MI Unggulan Darul Ulum dilaksanakan secara tematik, dimulai pukul 08.00 hingga selesai pada pukul 10.40. Setelah itu dilanjutkan, mata pelajaran pengembangan melalui berbagai kegiatan intrakurikuler (pelajaran Imla', Muhadatsah, dan Conversation), ekstrakurikuler (kegiatan renang, bermain musik, pramuka, melukis, menari dan jarimatika) dan kokurikuler (kegiatan pembiasaan untuk mengasah kemampuan kognitif, afektif, sekaligus psikomotorik yang meliputi; komunikasi bi lingual, praktik ibadah Shalat dhuha, qabliyah, dan field trip) dimaksudkan untuk diajarkan di siang hari hingga sore hari. Dari jadwal-jadwal yang ada secara tidak langsung program kelas unggulan di MI Darul Ulum Wates Ngaliyan Semarang ini menerapkan pembelajarn full day (sehari penuh). Setingkat siswa-siswi sekolah dasar untuk mengikuti kegiatan pembelajaran secara full day pasti akan banyak yang mengeluh, capek, bahkan bosan. Tetapi inilah salah satu strategi pembelajaran yang dijalankan di MI Darul Ulum Wates Ngaliyan Semarang melalui sistem-sistem pembelajaran yang cukup variatif. Untuk itu supaya kurikulum nasional dan lokal dapat berjalan dengan baik perlu kiranya sebuah lembaga pendidikan menerapkan manajemen kurikulum yang baik dan benar agar kegiatan kurikulum dapat berjalan sesuai dengan apa yang telah direncanakan sebelumnya serta dapat berjalan secara efektif dan efisien. Dengan pijakan beberapa hal unik yang ada di kelas unggulan MI Darul Ulum Wates Ngaliyan Semarang tersebut peneliti tertarik untuk melakukan penelitian dengan judul "Manejemen Kurikulum Kelas Unggulan di MI Darul Ulum Wates Ngaliyan Semarang".

\section{METODE PENELITIAN}

Jenis penelitian ini menggunakan jenis penelitian deskriptif. Tujuan penelitian deskriptif ini adalah untuk mendeskripsikan dan menggambarkan secara sistematis, faktual dan akurat

\footnotetext{
${ }^{1}$ Undang-Undang RI No.20 Tentang Sistem Pendidikan Nasional, issued 2003.

2 Farida Hanun, "Membangun Citra Madrasah Melalui Program Kelas Unggulan Di MTsN 2 Bandar Lampung," EDUKASI: Jurnal Penelitian Pendidikan Agama Dan Keagamaan 14, no. 3 (2016): 405-24, https://doi.org/http://dx.doi.org/10.32729/edukasi.v14i3.9.
} 
mengenai fakta-fakta, sifat-sifat serta hubungan antar fenomena yang sedang diselidiki. ${ }^{3}$ Selain itu, penelitian deksriptif merupakan penelitian yang sederhana, mudah dipahami, tanpa perlu adanya rumus-rumus statistika. Namun, penelitian ini juga memerlukan tindakan yang teliti pada setiap komponennya agar dapat mendeskripsikan subjek atau objek yang diteliti. ${ }^{4}$

Penelitian ini menggunakan pendekatan kualitatif. Pendekatan kualitatif adalah pendekatan yang dilakukan untuk memahami fenomena perilaku pendidik dan peserta didik dalam proses belajar mengajar. ${ }^{5}$ Peneliti menggunakan pendekatan kualitatif karena peneliti ingin memahami situasi yang sedang diteliti dan memahami hal-hal yang sudah direncanakan sebelumnya dan perealisasiannya. Pemahaman peneliti dan penjelasan orang-orang yang terlibat dalam perumusan strategi-strategi tersebut diharapkan saling melengkapi dan mampu menjelaskan fenomena yang sedang diteliti. ${ }^{6}$

Teknik pengumpulan data dilakukan melalui observasi secara langsung, wawancara dan diperkuat dengan data dokumentasi meliputi dokumen pribadi dan dokumen resmi yang semua dokumen yang dipaparkan tersebut berkaitan dengan lembaga pendidikan yang menjadi lokasi penelitian. Sedangkan untuk menguji keabsahan data menggunakan teknik triangulasi dengan memberikan pertanyaan yang sama kepada pihak yang akan dilibatkan. Kemudian diperkuat dengan hasil observasi dan dokumentasi yang peneliti lakukan.

Analisis data dilakukan melalui tiga proses, yaitu (1) reduksi data, dimana reduksi data dilakukan dengan cara merangkum dan memilih hal-hal yang penting. Dengan demikian data yang telah direduksi akan memberikan gambaran yang jelas, mudah dimengerti, dan mempermudah bagi peneliti untuk mencari data tersebut apabila diperlukan kembali. (2) Penyajian data, dimana penyajian data dilakukan dengan bentuk uraian singkat. Setelah dilakukan reduksi dan penyajian data, selanjutnya dilakukan (3) penarikan kesimpulan. Kesimpulan peneliti tentang manajemen kurikulum kelas unggulan di MI Darul Ulum Wates Ngaliyan Semarang ini akan menjawab tentang rumusan masalah yang telah dirumuskan sejak awal.

\section{Kurikulum Kelas Unggulan}

Hal yang perlu diperhatikan dalam penyusunan kurikulum adalah asas-asas kurikulum. Asas-asas ini menjadi dasar dalam penyusunan kurikulum. Terdapat empat asas kurikulum menurut Nasution, yaitu: 1) asas filosofis, 2) asas psikologis, 3) asas sosiologis, dan 4) asas organisatoris. ${ }^{7}$ Jadi penyusunan kurikulum pada kelas unggulan disusun atas asas-asas tersebut di atas.

Salah satu asas yang mendominasi dalam penyusunan kurikulum kelas unggulan adalah asas psikologis. Pada asas psikologis, aspek psikologi peserta didik dan aspek psikologi belajar merupakan dua aspek utama. Dari aspek psikologi peserta didik, kurikulum yang disusun disesuaikan untuk kepentingan peserta didik agar tercipta suasana pembelajaran yang menjamin berkembangnya bakat yang di miliki para peserta didik. Berdasarkan aspek psikologi belajar, kelakuan untuk belajar bagi peserta didik pada hakikatnya dapat dipengaruhi dari pertimbangan kurikulum yang disusun.

Implikasi yang diperoleh dari pendapat-pendapat di atas pada kurikulum kelas unggulan adalah kurikulum kelas unggulan memiliki perbedaan dengan kurikulum kelas reguler (nonunggulan). Perbedaan tersebut dapat dilihat dari segi pengembangan materi ajar, metode, sumber belajar, indikator pembelajaran, kompetensi pembelajaran, evaluasi, dan sebagainya. Kurikulum kelas unggulan disusun dan dikembangkan sesuai dengan perkembangan bakat peserta didik.

\footnotetext{
${ }^{3}$ Moh Nazir, Metode Penelitian (Bogor: Ghalia Indonesia, 2014). hlm. 43.

${ }^{4}$ Amos Neolaka, Metode Penelitian Dan Statistik(Bandung: Remaja Rosdakarya, 2014). hlm. 22.

${ }^{5}$ Tohirin, Metode Penelitian Kualitatif Dalam Pendidikan Dan Bimbingan Konseling (Jakarta: Rajawali Pers, 2012). hlm. 3.

${ }^{6}$ Samiaji Sarosa, Penelitian Kualitatif Dasar-Dasar(Jakarta:Indeks, 2012). hlm. 11.

${ }^{7}$ Sorimuda Nasution, Asas Asas Kurikulum (Jakarta: Bumi Aksara, 1999). hlm. 10-14.
} 
Syafaruddin \& Mesiomno mengatakan bahwa penerapan kurikulum yang optimal dengan dukungan sumberdaya yang ada akan mendorong peningkatan kinerja madrasah dalam wujud lulusan yang unggul dan kepuasan kerja personil madrasah serta masyarakat. Syafaruddin \& Mesiomno juga menyatakan bahwa:

Ada beberapa persoalan dalam pelaksanaan kurikulum yang harus diperhatikan, yaitu: (1) kualitas program yang diberikan; (2) guru yang dilibatkan dalam proses pembelajaran; (3) harapan yang diberikan oleh warga madrasah; (4) pengembangan teknik motivasi dan penggunaannya oleh madrasah untuk mencapai harapan; (5) alokasi waktu terhadap keragaman mata pelajaran atau aktivitasnya; (6) jenis pembelajaran yang digunakan (kelas, kelompok dan praktik, laboratorium); dan (7) cara memajukan pelajar melalui program pemantauan. ${ }^{8}$

Dalam bukunya Bafadal berpendapat bahwa pembelajaran unggulan bukanlah pembelajaran khusus dan dikembangkan hanya untuk siswa yang unggul, akan tetapi secara metodologis dan psikologis pembelajaran tersebut dapat membuat siswa merasakan dan mengalami proses belajar secara baik dan maksimal dan tentunya juga perlu memperhatikan kapasitas dari masing-masing peserta didik. Bafadal juga menyampaikan terdapat empat indikator pembelajaran unggulan, yaitu: ${ }^{9}$

a) Dapat melayani semua siswa;

b) Semua anak mendapatkan pengalaman belajar semaksimal mungkin;

c) Proses pembelajaran sangat bervariasi tergantung pada tingkat kemampuan anak yang bersangkutan; dan

d) Mampu mewujudkan perubahan (hasil) yang sangat signifikan dalam pengetahuan, sikap, maupun keterampilan peserta didik.

Agar kebutuhan pendidikan siswa pada kelas unggulan dapat dilayani dengan baik diperlukan kurikulum dan pembelajaran yang berbeda dari kelas reguler. Perubahan kurikulum diperlukan karena perbedaan karakteristik dan kebutuhan belajar, emosional, dan sosial dari siswa berbakat. Munandar mengatakan bahwa perlu adanya modifikasi kurikulum untuk siswa unggul atau berbakat. Modifikasi kurikulum tersebut terbagi menjadi empat bidang, yaitu materi (content) yang diberikan, proses atau metode pembelajaran, produk yang diharapkan dari siswa, dan lingkungan belajar. ${ }^{10}$

Siswa berbakat atau unggulan biasanya cenderung telah menguasai materi pokok bahasan sebelum materi itu diberikan, sehingga modifikasi konten kurikulum diperlukan. Konten kurikulum kelas unggulan yang bisa ditambahkan misalnya guru merencanakan serta menyiapkan materi yang lebih sulit dan kompleks, menyiapkan bahan yang lebih canggih. Program seperti kelas yang maju lebih cepat, belajar mandiri, sistem maju berkelanjutan seperti diterapkan oleh madrasah laboratorium dengan belajar modul dan pemadatan kurikulum (curriculum compacting) dapat membantu modifikasi konten. ${ }^{11}$

Modifikasi proses atau metode pembelajaran adalah cara lain untuk memberikan kurikulum berbeda bagi siswa yang memiliki kemampuan atau bakat istimewa. Dalam program tersebut guru dapat membuat modifikasi proses tanpa mengganggu kelancaran pembelajaran di dalam kelas. Contoh program yang dapat disampaikan di kelas unggulan adalah program yang menggunakan pertanyaan tingkat tinggi, simulasi, membuat kontrak belajar, menggunakan mentor, buku-buku yang sesuai untuk siswa berbakat, dan pemecahan masalah masa depan.

\footnotetext{
${ }^{8}$ Syafaruddin Syafaruddin and Mesiono Mesiomno, Pendidikan Bermutu Unggul(Bandung:Citapustaka Media, 2006), hlm 99.

${ }^{9}$ Ibrahim Bafadal, Manajemen Peningkatan Mutu Sekolah Dasar Dari Sentralisasi Menuju Desentralisasi (Jakarta: Bumi Aksara, 2003). hlm. 31.

${ }^{10}$ Utami Munandar, Pengembangan Kreativitas Anak Berbakat(Jakarta: Departemen Pendidikan Nasional bekerjasama dengan Rineka Cipta, 2009). hlm. 138.

${ }^{11}$ Munandar, Pengembangan Kreativitas.... hlm. 140.
} 
Salah satu isi kurikulum untuk siswa berbakat adalah modifikasi produk belajar. Siswa berbakat atau unggul dapat menggunakan kemampuan mereka untuk mendalami topik dan menunjukkan kreativitas dan komitmen dalam merancang produk-produk divergen berdasarkan pengalaman belajarnya. Guru memberikan beberapa alternatif kepada siswa mengenai produk yang akan dihasilkan dan kesempatan untuk merancang produknya sendiri.

Keberhasilan program kelas unggulan diperlukan lingkungan yang berpusat pada siswa, sehingga yang awalnya pada kelas tradisonal berpusat pada guru diubah menjadi berpusat kepada siswa. Seperti yang dikemukakan Munandar yang mengutip dari penjelasan Paker, menyatakan ciri-ciri lingkungan yang berpusat kepada siswa sebagai berikut. a) Siswa menjadi mitra dalam membuat keputusan tentang kurikulum. b) Pola duduk yang memudahkan belajar. c) Kegiatan dan kesibukan di dalam kelas. d) Rencana belajar yang diindividualkan. e) Keputusan dibuat bersama oleh guru dan siswa jika mungkin.

Pada kelas unggulan guru berperan sebagai fasilitator dalam pembelajaran. Oleh karena itu, dalam praktiknya pembelajaran unggulan menuntut adanya tenaga profesional yang memadai sebagai guru khusus kelas unggulan. ${ }^{12}$ Munandar menyatakan bahwa terdapat ciri-ciri guru untuk siswa berbakat istimewa atau unggulan, yaitu: 1) sikap demokratis; 2) ramah dan memberi perhatian perorangan; 3) sabar; 4) minat luas; 5) penampilan yang menyenangkan; 6) adil; 7) rasa humor; 8) perilaku konsisten; 9) menggunakan penghargaan dan pujian; dan 10) kemahiran yang luar biasa dalam mengajar subjek tertentu. Ciri-ciri tersebut harus ada karena siswa dengan bakat yang istimewa atau unggul dapat bereaksi dengan kemarahan, kebencian, atau kesebalan jika guru menekan mereka.

Hal yang dapat diambil dari kutipan-kutipan di atas adalah bahwa kurikulum pada kelas unggulan dimodifikasi dengan pertimbangan adanya perbedaan individu (individual differences) yang dimiliki oleh siswa kelas unggulan. Dalam pelaksanaan kurikulum siswa kelas unggulan diperlukan adanya keterlibatan berbagai pihak mulai dari kalangan internal madrasah (kepala madrasah, wakil kepala madrasah, guru, staf pegawai) dan kalangan eksternal madrasah (komite madrasah, mentor, psikolog, dan orangtua siswa).

\section{HASIL PENELITIAN DAN PEMBAHASAN}

Sesuai data yang didapat selama penelitian, bahwa program kelas unggulan adalah tindak lanjut dari program tahasus yang sudah pernah terjalankan di MI Darul Ulum, yang meluluskan siswa siswi yang hafidz 3-4 juz yang bekerjasama dengan Darul Qur' an, setelah itu tidak jalan ternyata surut dan butuh wadah penanganan khusus sehingga di adakanlah program kelas unggulan dengan penambahan program-program unggul selain tahfidz. Hal itu menandakan anak berbakat dan mempunyai kelebihan memang harus di wadahi. Sebagaimana penjelasan yang di keluarkan oleh Direktorat Pendidikan Dasar dalam buku Pedoman Penyelenggaraan Kelas Unggulan bahwa anak didik yang prestasinya menonjol harus dikelompokkan dalam satu kelas tertentu kemudian di beri program pengajaran yang sesuai dengan kurikulum yang dikembangkan dan adanya tambahan materi pada mata pelajaran tertentu. Hal itu bertujuan untuk mengembangkan kemampuannya, karena jika materi yang disampaikan kepada anak didik yang mempunyai kelebihan itu materi yang biasa-biasa saja, pastinya mereka tidak akan tertantang dan akhirnya tidak berkembang dengan baik.

Sebagaimana teori Davis yang dikutip oleh Munandar menyatakan bahwa terdapat ciriciri guru untuk siswa berbakat istimewa atau unggulan. Ciri-ciri guru tersebut adalah: 1) sikap demokratis; 2) ramah dan memberi perhatian perorangan; 3) sabar; 4) minat luas; 5) penampilan yang menyenangkan; 6) adil; 7) rasa humor; 8) perilaku konsisten; 9) menggunakan penghargaan dan pujian; dan 10) kemahiran yang luar biasa dalam mengajar subjek tertentu. Ciri-ciri yang

${ }^{12}$ Munandar, Pengembangan Kreativitas.... hlm.100. 
harus ada pada guru yang mengajar kelas unggulan tersebut lah yang menjadi alat dalam penyeleksian guru kelas unggulan di MI Darul Ulum Wates Ngaliyan Semarang selain kemampuan dan kecakapan berbahasa arab dan inggris sebagai poin tambahan, karena siswa dengan bakat yang istimewa atau unggul dapat bereaksi dengan kemarahan, kebencian, atau kesebalan jika guru menekan mereka.

Sebagaimana yang dijelaskan dalam Pasal 8 dan 9 UU No.14 tahun 2005: Tentang Guru dan Dosen, bahwa guru wajib memiliki kualifikasi akademik, kompetensi, sertifikat pendidik, sehat jasmani dan rohani, serta memiliki kemampuan untuk mewujudkan tujuan pendidikan nasional. Kualifikasi akademik sebagaimana dimaksud dalam pasal 8 diperoleh melalui pendidikan tinggi program sarjana (S1) atau program diploma empat. Sesuai dengan peraturan tersebut dan data jumlah ketenagaan dan lulusan dinyatakan bahwa guru yang mengajar intrakurikuler $100 \%$ sudah melalui pendidikan strata 1.

Dirincikan lagi mengenai Standar Kualifikasi Akademik dan Komponen Guru dalam Permendiknas Nomor 16 Tahun 2007. Guru pada SD/MI atau bentuk lain yang sederajat, harus memiliki kualifikasi pendidikan akademik minimal diploma empat (D-IV) atau sarjana (SI) dalam bidang pendidikan SD/MI (D-IV/SI PGSD/PGMI) atau psikologi yang diperoleh dari program studi yang terakreditasi. Untuk dapat diangkat sebagai guru dalam bidang-bidang khusus yang sangat diperlukan, kualifikasi akademik yang dipersyaratkan diatur dalam permendiknas Nomor 16 Tahun 2007, tetapi belum dikembangkan di perguruan tinggi, dapat diperoleh melalui uji kelayakan dan kesetaraan. Uji kelayakan dan kesetaraan bagi seseorang yang memiliki keahlian tanpa ijazah, dilakukan oleh perguruan tinggi yang diberi wewenang untuk melaksanakannya. Adapun dari data kuantitas dan kualitas guru MI Darul Ulum, meskipun semua guru sudah melalui pendidikan tinggi program sarjana (S1) tetapi masih ada beberapa yang belum bersertifikasi, dan 7 guru kelas unggulan termasuk guru yang terbilang baru dan belum bersertifikasi. Namun kualifikasi pendidikannya dalam bidang pendidikan walaupun tidak semua dalam bidang pendidikan guru madrasah ibtidaiyah (PGMI). Keadaan inilah yang nantinya menjadi hal yang harus diperbaiki oleh MI Darul Ulum, untuk terus meningkatkan kompetensi guru-guru yang mengajar didalamnya demi menjaga mutu pendidikan baik melalui studi lanjut, PLPG, PPG, maupun workshop.

Beralih ke rasio siswa dan guru yang ideal, sesuai dengan apa yang tercantum dalam Keputusan Direktur Jenderal Pendidikan Islam Kemenag Nomor: 7263 Tahun 2018 tentang Petunjuk Teknis Penyaluran Tunjangan profesi Guru Bagi Guru Madrasah Tahun 2019 (Bab III Poin 9), aturan terkait rasio minimal jumlah siswa terhadap guru bagi Madrasah Ibtidaiyah adalah 15:1. Selain ketentuan minimal jumlah siswa, yang tidak kalah pentingnya adalah aturan terkait jumlah maksimal siswa dalam satu rombel, jumlah maksimal rombel dalam satu tingkat dan jumlah maksimal rombel dalam satu madrasah, untuk ketentuan Madrasah Ibtidaiyah, maksimal $54 \mathrm{rombel} / \mathrm{madrasah}$ dan 9 rombel/tingkat dengan jumlah siswa maksimal 28 siswa/rombel. Panduan tersebut ternyata juga menjadi bahan pertimbangan penerimaan siswa-siswi unggulan di MI Darul Ulum Wates Ngaliyan, demi kualitas pelayanan kelas unggulan secara maksimal sehingga pembelajaran juga efektif maka dibuat penugasan pendampingan 2 guru kelas bagi rombel yang melebihi 20 peserta didik. Dan setelah menganalisis data ternyata masih ada kelas yang dihuni 27 peserta didik dan didampingi 1 guru kelas tepatnya di kelas 3 unggulan, hal itu dijawab oleh kordinator tim pengembang kelas unggulan bahwa akan segera diadakan open reqruitment guru kelas unggulan lagi untuk tetap menjaga kualitas pelayanan secara maksimal. Dari pemaparan data dan realita tersebut rasio guru dengan siswa kelas unggulan di MI Darul Ulum sudah sesuai dan diterapkan dengan baik.

Dalam deskripsi data juga jelas muatan kurikulum bagi kelas unggulan di MI Darul Ulum Wates Ngaliyan lebih banyak dari kelas reguler karena kelas unggulan menerapkan sistem full day school, dan itu semua didukung dengan adanya fasilitas yang memadai dan metode-metode yang variatif. Nilai-nilai hasil ujian akhir semester perbandingan antara kelas unggulan dan 
reguler juga perbedaanya menonjol dengan muatan lokal yang berbeda dan beban jam yang selisih.

Adapun temuan khusus mengenai manajemen kurikulum kelas unggulan di MI Darul Ulum hasil analisisnya sebaga berikut:

\section{Perencanaan Kurikulum Kelas Unggulan}

Dalam membuat sebuah perencanaan terhadap kurikulum, banyak hal yang harus dipertimbangkan secara matang, di antaranya adalah bagaimana kita melakukan manajemen atau pengelolaan terhadap perencanaan kurikulum itu sendiri. Pengelolaan terhadap perencanaan kurikulum sangat bergantung pada kemampuan manusia sebagai pengelolanya. Apabila pengelolaan perencanaan kurikulum ini dilaksanakan oleh seorang profesional, akan dihasilkan sebuah "master plan" kurikulum yang siap untuk diujicobakan ataupun diterapkan pada sasaran yang telah ditetapkan.

Perencanaan kurikulum program kelas unggulan di MI Darul Ulum Wates Ngaliyan Semarang sudah baik yang mana perencanaan dilakukan dengan menganalisis konteks, kebutuhan dan standar nasional pendidikan, setelah itu dilanjut dengan pemilihan atau penetapan tujuan dan penentuan strategi, kebijakan, program, prosedur, metode, sistem, anggaran dan standar yang dibutuhkan untuk mencapai tujuan pendidikan.

Di sisi lain perencanaan tidak bisa direncanakan oleh pimpinan dan diputuskan oleh beberapa orang saja, sebagaimana yang dijelaskan Dr. H. Dinn Wahyudin, MA dalam buku karyanya bahwa perencanaan dan pengembang kurikulum paling efektif jika dikerjakan secara bersama-sama untuk itulah peran berbagai pihak dalam perencanaan sangat dibutuhkan. ${ }^{13}$ Sesuai dengan hasil observasi dan wawancara yang dilakukan peneliti, bahwa perencanaan kurikulum pada kelas unggulan di MI Darul Ulum Wates Ngaliyan Semarang dilakukan oleh kepala madrasah bersama pengurus yayasan dan komite madrasah atau juga bisa disebut tim khusus dan dibantu dengan tim pengembang dibawahnya, keterlibatan berbagai pihak seperti itulah yang akan membantu perwujudan dari perencanaan secara maksimal.

Program kelas unggulan di MI Darul Ulum menyelenggarakan kegiatan pembelajaran berdasarkan Kurikulum Nasional Tahun 2013 yang dikombinasi dengan kurikulum muatan lokal. Dimana pengembangan muatan lokal yang digunakan adalah pelajaran Imla', Muhadatsah, dan Conversation. Kegiatan pengembangan diri dengan mengadakan kegiatan ekstrakurikuler yang terdiri dari kegiatan renang, bermain musik, pramuka, melukis, menari dan jarimatika. Yang mana kegiatan pembelajaran Kurikulum Nasional dilaksanakan secara tematik, dimulai pukul 08.00 hingga selesai pada pukul 10.40. Selanjutnya, mata pelajaran pengembangan diajarkan di siang hari hingga sore hari. Kegiatan belajar mengajar sendiri dimulai pada hari Senin dan berakhir hari Jum' at, sedang hari Sabtu-nya diisi dengan kegiatan ekstra kurikuler berupa praktik renang dan bermain musik (kombinasi).

Perencanaan kurikulum kelas unggulan yang dilaksanakan di MI Darul Ulum Wates Ngaliyan Semarang adalah penentuan standar-standar, salah satunya adalah penentuan standar kelulusan madrasah. Standar kompetensi lulusan program kelas unggulan MI Darul Ulum Wates Ngaliyan yaitu: 1) Bisa membaca kitab kuning, 2) Lancar baca dan tulis al-Qur' an, 3)Wajib hafal Juz 30, surat-surat pilihan (Yasin, Waqi' ah, Ar-Rahman, Al-Mulk dll.) dan Juz 29 yang dimulai dari kelas 3, 4) Mampu menguasai Bahasa Arab dan Bahasa Inggris.

Pelaksanaan pembelajaran dalam kelas unggulan akan dilengkapi dengan modul/buku pedoman yang akan memudahkan para siswa belajar khususnya mengenai kemampuan berbahasa arab inggris, baca kitab kuning dan juga tahfidz. Hal ini berkenaan dengan pengajaran yang tepat bagi siswa berbakat intelektual. Tirtonegoro menyarankan sistem pengajaran kelas unggulan dengan menggunakan sistem modul karena dianggap paling sesuai dengan karakteristik siswa berbakat intelektual dengan segala potensi dan karakteristiknya, dan hal ini

\footnotetext{
${ }^{13}$ Dinn Wahyudin, Manajemen Kurikulum (Bandung: Remaja Rosdakarya, 2014). hlm. 23.
} 
juga diperkuat dalam tulisan Ahmad Zarkasy yang dimuat Jurnal Al-Makrifat Vol 1, No 1, April 2016 bahwa untuk mengetahui mengapa sistem modul diharapkan dapat mengembangkan potensi siswa gifted and talented karena: a) Memberi penekanan kepada kesempatan belajar mandiri yang aktif pada siswa. b) Memperhatikan perbedaan kecepatan belajar siswa. c) Kejelasan dalam penyajian dalam bentuk tingkah laku siswa bagi setiap satuan pengajaran yang terkecil. d) Penggunaan berbagai media dan metode sesuai dengan sifat dan hakikat bahan dan tujuan pelajaran. e) Kemungkinan siswa berpartisipasi secara aktif dalam seluruh proses belajar mengajar. f) Umpan balik langsung dari hasil penilaian secara terus menerus. ${ }^{14}$

Selain itu, MI Darul Ulum Wates Ngaliyan Semarang juga sudah merencanakan akan melakukan kunjungan belajar ke luar negeri dan juga melakukan kerjasama dengan Kampung Inggris Pare untuk meningkatkan pengetahuan anak didik tentang Bahasa Inggris dan Bahasa Arab, serta menyekolahkan kembali para guru yang tahfidz dan pengampu pembelajaran kitab kuning ke pondok-pondok pesantren terbaik. Hal ini menunjukkan bahwa inovasi-inovasi selalu dikembangkan untuk meningkatkan kualitas program kelas unggulan yang sudah berjalan.

\section{Pengorganisasian Kurikulum Kelas Unggulan}

Berdasarkan apa yang disampaikan oleh kepala MI Darul Ulum Wates Ngaliyan bahwa untuk kordinator tim pengembang kurikulum yaitu dari tenaga profesional madrasah, yang di bawahnya beranggotakan guru-guru senior dan beberapa pengurus komite lainnya. Setelah ditentukan kordinator tim pengembang kurikulum maka kordinator tim memilih anggotaanggota yang dijadikan tim pengembang kurikulum. Yang nantinya sebagai tim inti pelaksanaan pengembangan kurikulum sampai ke evaluasi pengembangan kurikulum. Tugas tim pengembangan kurikulum yaitu merealisasikan dan menyusun kurikulum dari rencana yang telah dibuat oleh kepala madrasah, pengurus yayasan, dan pengurus komite madrasah. Hal ini disampaikan oleh kordinator tim pengembang adalah melaksanakan apa yang telah direncanakan oleh tim khusus dan menyusunnya menjadi sebuah dokumen kurikulum dari hasil pengembangan yang telah dilakukan.

Madrasah juga mengorganisir seluruh kegiatan akademik maupun non akademik sampai terjadwal dengan baik sehingga tidak ada jadwal yang saling bertabrakan. Mencermati kutipankutipan yang disampaikan oleh pihak-pihak yang bersangkutan, bahwa pengorganisasian kurikulum pada program kelas unggulan di MI Darul Ulum sudah semaksimal mungkin dilakukan dan melewati beberapa tahap, mulai dari:

a Tahap pembagian tugas dan wewenang oleh tim khusus kepada tim pengembang.

b Tahap pembagian tugas mengajar dan tugas-tugas lain yang dilakukan secara merata, sesuai dengan keahlian dan ketentuannya.

c Tahap penyusunan jadwal pelajaran dan beban jam mengajar bagi guru yang disesuaikan dengan standar pelayanan minimal mengajar

d Tahap penyusunan jadwal kegiatan, baik kegiatan intrakurikuler maupun kegiatan ekstrakurikuler

Pengorganisasian sumber daya di MI Darul Ulum Wates Ngaliyan yakni dapat diketahui melalui beberapa poin-poinnya sebagai berikut:

a Segala peraturan madrasah dan mekanisme manajemen madrasah dikomandoi secara penuh dan terorganisir oleh Kepala Madrasah.

b Mekanisme perencanaan program dilaksanakan pada rapat kerja tahunan yang diikuti oleh seluruh elemen madrasah, yakni Kepala Madrasah, Kordinator tim Litbang, Guru, staf, dan wali murid. Kegiatan ini telah terlaksana secara continue dan berjalan dengan baik.

c Program kerja telah diaktualisasikan oleh masing-masing anggota dan pimpinan sesuai dengan jobdisnya.

${ }^{14}$ Ahmad Zarkasyi, "Konsep Pengembangan Program Unggulan Di Lembaga Pendidikan Islam," Jurnal Al-Makrifat 1, no. 1 (2016): 35-52. 
d MI Darul Ulum Wates Ngaliyan Semarang memiliki target madrasah dalam satu tahun yang harus tercapai bahkan terlampaui.

e Seluruh siswa diharapkan aktif dan kompetitif dalam mengikuti kegiatan belajar mengajar dan ekstrakulikuler yaitu harapannya agar siswa dapat menyalurkan bakat dan minatnya.

f MI Darul Ulum Wates Ngaliyan senantiasa memfasilitasi kebutuhan belajar siswa.

Secara keseluruhan sistem organisasi di MI Darul Ulum Wates Ngaliyan Semarang dapat dikatakan memenuhi kualifikasi sistematis, efisien dan terorganisir, hanya saja ada yang harus diperbaiki dalam pendokumentasian job description, pembagian tugas tersebut harus didokumentasikan baik dalam bentuk tulisan maupun bagan koordinasi, untuk memudahkan dalam pengembangan dan evaluasi, karena di kantor madrasah juga belum melakukan pengadaan papan struktur madrasah.

\section{Pelaksanaan Kurikulum Kelas Unggulan}

Bentuk dari pelaksanaan kurikulum ialah proses belajar dan mengajar yang sesuai dengan prinsip-prinsip kurikulum yang telah ditetapkan, Dari kutipan-kutipan wawancara di atas dapat diketahui bahwa peranan kepala madrasah dalam fungsi pelaksanaan kurikulum pada program kelas unggulan dilakukan dengan melakukan kegiatan pengawasan terhadap pelaksanaan kurikulum. Adanya kesepakatan mengajar bagi guru pada program kelas unggulan menjadikan kinerja guru lebih mudah diawasi oleh kepala madrasah. Peranan guru program kelas unggulan dalam fungsi pelaksanaan kurikulum adalah dengan melakukan pembelajaran yang dengan prinsip dan model pembelajaran yang sesuai dengan tuntutan kurikulum.

Adapun pelaksanaan pembelajaran yang diterapkan dalam kelas unggulan sudah sesuai dengan isi kurikulum 2013 yang mengembangkan prinsip pembelajaran yang berpusat pada siswa. dan kegiatan-kegiatan implementasi RPP dan penilaian yang dilakukan guru juga berpedoman dengan Permendikbud Nomor 22 Tahun 2016 Tentang Standar Proses Pendidikan Dasar dan Menengah yang meliputi kegiatan pendahuluan, inti (mengamati, menanya, mengumpulkan informasi, mengasosiasi, mengkomunikasikan) dan penutup.

Hal yang membedakan pelaksanaan kelas unggulan di MI Darul Ulum Wates Ngaliyan dengan di madarasah lain yakni salah satunya keunggulan pada sistem pembelajaran tambahannya, kelas unggulan di MI Darul Ulum Wates Ngaliyan menggunakan sistem pembelajaran: 1) Field Trip, adanya sistem Field Trip ini diharapkan siswa dapat memperoleh pengalaman langsung dari objek yang dilihatnya, dapat turut menghayati tugas pekerjaan milik seseorang serta dapat bertanggung jawab. 2) Home Visiting, salah satu dari beberapa metode yang digunakan Madrasah untuk menjalin dan mengakrabkan hubungan antara Madrasah dengan orangtua peserta didik. 3) Fun Learning Activities(FLA), yaitu kegiatan pembelajaran yang menyenangkan yang di dalamnya adalah adanya keterlibatan orang tua dan masyarakat secara aktif disamping pendidik yang professional. 4) Parent Teaching, tujuan dari kegiatan ini adalah untuk meningkatkan kerja sama antara guru dan orang tua. Mereka juga memberikan pendidikan kepada anak-anak secara langsung melalui ahli bahwa orang tua mereka dapat mengajari sesuai dengan keahlian mereka.

Berdasarkan analisis peneliti mengenai pelaksanaan kelas unggulan di MI Darul Ulum Wates Ngaliyan Semarang terdapat beberapa komponen yang dimana komponen-komponen tersebut merupakan alat untuk keberhasilan pelaksanaan kelas unggulan di MI Darul Ulum Wates Ngaliyan Semarang diantaranya yaitu:

a Input peserta didik yaitu menyeleksi calon peserta didik dilakukan mulai dari tahap seleksi administrasi, seleksi kompetensi dasar sesuai pedoman tumbuh kembang anak, seleksi minat, bakat dan prestasi.

b Guru kelas unggulan memiliki kemampuan keterampilan dalam mengajar, mempunyai keteladanan, dan mempunyai target yang dituju. Poin khususnya bisa berbahasa arab dan inggris, tahfidz dan bisa membaca kitab kuning. 
c Kurikulum kelas unggulan telah dimodifikasi menyesuaikan dengan visi dan misi madrasah dan sudah mewadahi secara spiritual, logika, etika, dan estetika serta mengembangkan kemampuan berpikir, kreatif, sistemik dan sistematis.

d Sumber pembelajaran. Sumber pembelajaran yang diberikan pada kelas unggulan berupa buku, buku teks, buku modul, LCD/proyektor, dan materi yang disampaikan oleh guru secara langsung.

e Sistem pembelajaran menggunakan strategi yang khusus, disaat KBM guru membiasakan dengan menggunakan 2 bahasa (arab dan inggris).

f Media pembelajaran tesedianya fasilitas khusus sebagai media pembelajaran di kelas unggulan.

g Tercapainya standar kompetensi lulusan program kelas unggulan MI Darul Ulum Wates Ngaliyan yaitu: 1) Bisa membaca kitab kuning, 2) Lancar baca dan tulis al-Qur' an 3) Wajib hafal Juz 30 dan surat-surat pilihan (Yasin, Waqi' ah, Ar-Rahman, Al-Mulk dll.) Juz 29 dimulai kelas 3, 4) Mampu menguasai Bahasa Arab dan Bahasa Inggris.

$\mathrm{h}$ Evaluasi setiap akhir semester berupa tes lisan berbahasa Arab, Inggris, hafalan surat pendek, dan praktik ibadah amaliyah.

Dari beberapa komponen alat penilaian keberhasilan kurikulum program kelas unggulan di MI Darul Ulum Wates Ngaliyan, poin ke-7 lah yang belum berhasil tercapai, karena adanya program kelas unggulan di MI Darul Ulum baru masuk tahun ke-5 dan belum meluluskan peserta didik. Tetapi, sesuai hasil wawancara dengan wali murid perkembangan anak selama masuk kelas unggulan begitu signifikan dan jauh lebih baik.

\section{Evaluasi Kurikulum Kelas Unggulan}

Secara umum evaluasi dibedakan menjadi dua yaitu evaluasi proses pembelajaran dan evaluasi hasil belajar, mencermati hasil wawancara menyatakan bahwa kedua evaluasi tersebut telah dilaksanakan pada program kelas unggulan di MI Darul Ulum dengan baik.

Pertama. Evaluasi proses pembelajaran, komponen yang dievaluasi dalam pembelajaran bukan hanya hasil belajar mengajar tetapi keseluruhan pelaksanaan program pembelajaran, metode, media serta komponen evaluasi pembelajaran. Ada beberapa prinsip evaluasi pendidikan yang harus diperhatikan oleh evaluator dalam menjalankan tugasnya. Prinsip tersebut yaitu: harus mengacu pada tujuan pembelajaran, dilaksanakan secara obyektif, dilaksanakan secara komprehensif atau menyeluruh, dilaksanakan secara terus menerus.

Kedua. Evaluasi hasil belajar, dalam evaluasi ini MI Darul Ulum menggunakan penilaian formatif dan sumatif:

a Penilaian Formatif, ditujukan untuk menilai penguasaan siswa terhadap tujuan-tujuan belajar atau kompetensi dasar dalam jangka waktu yang relatif pendek. Dalam kurikulum pendidikan dasar dan menengah evaluasi formatif digunakan untuk menilai penguasaan siswa setelah siswa mempelajari satu pokok bahasan. Seperti kuis awal dan akhir pembelajaran.

b Penilaian Sumatif, ditujukan untuk menilai penguasaan siswa terhadap tujuan-tujuan atau kompetensi yang lebih luas, sebagai hasil usaha belajar dalam jangka waktu yang cukup lama. Seperti satu semester, satu tahun atau selama jenjang pendidikan. Kalau evaluasi melalui cara penilaian ini juga dilakukan oleh wali murid yang melihat perkembangan anak dan selalu dibahas dalam paguyuban kelas, sehingga apa yang kurang baik dan apa masukan dari wali murid selalu ditampung oleh guru dan ditembuskan kepada kepala madrasah, kegiatan ini biasanya dilakukan setelah rutinan home visiting yang bersifat giliran.

Sesuai deskripsi data hasil wawancara dengan tenaga pendidik dan peserta didik tersebut juga relevan dengan Peraturan Menteri Pendidikan dan Kebudayaan Republik Indonesia Nomor 23 Tahun 2016 Tentang Standar Penilaian Pendidikan pada bab V Bab bentuk Penilaian pasal 6 dan 7. 
Pentingnya evaluasi (khususnya evaluasi hasil belajar) adalah dapat memberikan dorongan (motivasi) kepada mereka untuk dapat memperbaiki, meningkatkan dan mempertahankan prestasinya. Evaluasi pembelajaran kelas unggulan di MI Darul Ulum, guru sudah melakukan pelaksanaan pembelajaran cukup baik, nilai peserta didik rata-rata sudah mencapai KKM, dan selalu ada peningkatan tiap tahunnya. Apabila belum mencapai akan ada pemaksimalan yaitu dengan melakukan remidial.

\section{SIMPULAN}

Berdasarkan hasil penelitian yang telah dilakukan peneliti, mulai dari deskripsi data sampai analisisnya yang berjudul "Manajemen Kurikulum Kelas Unggulan di MI Darul Ulum Wates Ngaliyan Semarang". Maka, didapatlah kesimpulan sebagai berikut:

1. Perencanaan kurikulum kelas unggulan di MI Darul Ulum Wates Ngaliyan Semarang disusun oleh tim khusus dibantu tim pengembang dibawahnya. Perencanaan dilakukan dengan menganalisis konteks, kebutuhan dan standar nasional pendidikan, setelah itu dilanjut dengan pemilihan atau penetapan tujuan dan penentuan strategi, kebijakan, program, prosedur, metode, sistem, anggaran dan standar yang dibutuhkan untuk mencapai tujuan pendidikan. Sistem pengajaran dengan menggunakan sistem modul. Perencanaan guru meliputi program tahunan, program semester, silabus, dan rencana pelaksanaan pembelajaran (RPP). Penyeleksian calon siswa dan calon guru dilakukan secara selektif sesuai dengan panduan penyeleksian yang telah ditetapkan.

2. Pengorganisasian kurikulum kelas unggulan di MI Darul Ulum Wates Ngaliyan Semarang dilakukan dalam beberapa tahap, diantaranya: a. Tahap pembagian tugas dan wewenang oleh tim khusus kepada tim pengembang. b. Tahap pembagian tugas mengajar dan tugas-tugas lain yang dilakukan secara merata, sesuai dengan keahlian dan ketentuannya. c. Tahap penyusunan jadwal pelajaran dan beban jam mengajar bagi guru yang disesuaikan dengan standar pelayanan minimal mengajar. d. Tahap penyusunan jadwal kegiatan, baik kegiatan intrakurikuler maupun kegiatan ekstrakurikuler.

3. Bentuk dari pelaksanaan kurikulum kelas unggulan di MI Darul Ulum Wates Ngaliyan Semarang ialah proses belajar dan mengajar yang sesuai dengan prinsip-prinsip kurikulum yang telah ditetapkan. Peranan kepala madrasah dalam fungsi pelaksanaan kurikulum pada program kelas unggulan dilakukan dengan melakukan kegiatan pengawasan terhadap pelaksanaan kurikulum. Adanya kesepakatan mengajar bagi guru pada program kelas unggulan menjadikan kinerja guru lebih mudah diawasi oleh kepala madrasah. Peranan guru program kelas unggulan dalam fungsi pelaksanaan kurikulum adalah dengan melakukan pembelajaran yang dengan prinsip dan model pembelajaran yang sesuai dengan tuntutan kurikulum.

4. Evaluasi kurikulum kelas unggulan di MI Darul Ulum Wates Ngaliyan Semarang menggunakan dua macam evaluasi yaitu evaluasi proses pembelajaran dan evaluasi hasil belajar melalui penilaian formatif dan sumatif.

\section{DAFTAR PUSTAKA}

Bafadal, Ibrahim. Manajemen Peningkatan Mutu Sekolah Dasar Dari Sentralisasi Menuju Desentralisasi. Jakarta: Bumi Aksara, 2003.

Hanun, Farida. "Membangun Citra Madrasah Melalui Program Kelas Unggulan di MTsN 2 Bandar Lampung." EDUKASI: Jurnal Penelitian Pendidikan Agama Dan Keagamaan 14, no. 3 (2016): 405-24. https://doi.org/http://dx.doi.org/10.32729/edukasi.v14i3.9.

Munandar, Utami. Pengembangan Kreativitas Anak Berbakat. Jakarta: Departemen Pendidikan 
Nasional bekerjasama dengan Rineka Cipta, 2009.

Nasution, Sorimuda. Asas Asas Kurikulum. Jakarta: Bumi Aksara, 1999.

Nazir, Moh. Metode Penelitian. Bogor: Ghalia Indonesia, 2014.

Neolaka, Amos. Metode Penelitian Dan Statistik. Bandung: Remaja Rosdakarya, 2014.

Sarosa, Samiaji. Penelitian Kualitatif Dasar-Dasar. Jakarta:Indeks, 2012.

Syafaruddin, Syafaruddin, and Mesiono Mesiomno. Pendidikan Bermutu Unggul.

Bandung:Citapustaka Media, 2006.

Tohirin. Metode Penelitian Kualitatif Dalam Pendidikan Dan Bimbingan Konseling. Jakarta:

Rajawali Pers, 2012.

Undang-Undang RI No.20 Tentang Sistem Pendidikan Nasional, issued 2003.

Wahyudin, Dinn. Manajemen Kurikulum. Bandung: Remaja Rosdakarya, 2014.

Zarkasyi, Ahmad. "Konsep Pengembangan Program Unggulan Di Lembaga Pendidikan Islam." Jurnal Al-Makrifat 1, no. 1 (2016): 35-52. 